\title{
1. Introduction: identifying and explaining governance virtuous circles
}

\section{Alina Mungiu-Pippidi}

\subsection{WHAT IS INSTITUTIONALIZED CORRUPTION? OUR CONCEPTS}

From the beginning of government, humans have struggled with the problem of fair distribution of joint resources, and with the difficulty of preventing those with greater power and access from cutting the lion's share off for themselves. Democratization and the exponential growth of the state, and therefore of common resources, have made this problem paramount; and presently there is no day when we do not witness serious challenges to executive leaders on corruption grounds: from the prime minister of Iceland stepping down over mere allegations, to the presidents of Brazil and South Korea who were impeached. The high integrity standards have expanded from a minority of developed countries by norm promotion and modernization, culminating in the United Nations Convention against Corruption (UNCAC) in 2003. The UNCAC establishes fairness, equality, transparency, accountability and public participation as the foundations of good governance. More and more citizens from a growing number of countries, who are probably unaware that the convention even exists, have presently come to demand that their governments deliver good governance. The unprecedented extension of elections after the Third Wave of democratization brought roughly half the world's countries into a situation where their people have sufficient freedom to demand equal treatment by the government, only to discover that public corruption is the chief obstacle. Achieving control of corruption thus becomes the indispensable final stage of a successful democratization process (Johnston 2014).

In the academic world as well, after many years of being marginal, corruption has resurfaced as a major issue. Following the post-Washington Consensus revelation that governance matters greatly in explaining development, the issue of institutional change, which a few decades ago was of 
interest only to students of Mancur Olson or Douglass North, has risen to the forefront not only for economists but also for the international donor community. Corruption, of course, is ubiquitous. Johnston (2005) showed how corruption takes the form of different syndromes across societies according to power distribution, natural resources and societal constraints: driven by elite cartels (as found in Botswana, Italy and Korea) or oligarchs and clans (as in Mexico, the Philippines and Russia, with rival groups competing for government favors in an institutionally weak state) or official moguls (as in China, Indonesia and Kenya, where political leaders used to despoil public resources with impunity). Even when institutions and legal systems are relatively strong, an undue business-politics connection might try to influence markets to get favorable treatment (as in Germany, Japan and the United States). We may not know much about why some societies managed to evolve to have better control over corruption and others not, but we do know quite well how the former differ presently compared to the latter. In a time-series model, Mungiu-Pippidi (2015a, ch. 4) showed that corrupt societies have not managed to balance the opportunities for corruption (such as natural resources, red tape, high power inequality and lack of transparency) with the constraints on elite behavior (through independence of the judiciary, freedom of the press and enlightened citizens).

But how to reach this equilibrium, or in other words how to engineer this development, remains far less consensual, if altogether known. As Claus Offe has argued, we still have insufficient knowledge of what could bring countries out of the vicious circle of corrupt institutions: "which motives, values, and political forces would actually push forward the reform project ... what are the incentives to introduce incentives designed to control corruption or to redesign opportunity structures?" (2004, p. 91). In other words, what makes a governance order based on what Max Weber described as patrimonialism evolve to ethical universalism (equal and fair treatment for everyone) by design, rather than through a long historical evolution; and can such transformations be engineered by human agency? These are the main questions of this book.

The concept of the virtuous circle had been used for quite a while in development studies before the best-selling Why Nations Fail suggested that a virtuous circle is based on a passage from extractive to inclusive institutions (Acemoglu and Robinson 2012a); or, in other words, that it accomplishes in the initial stage exactly the kind of transformation of interest to us in this research. Explaining the difference in economic performance across countries by some governance virtuous circle is tempting, except that such governance virtuous circles need explaining themselves. In terms of neo-institutionalism theory, an equilibrium can only change when those who profit from the status quo (the so-called 
institutional winners) give away some of their advantage in favor of institutional losers. While historians are generally reluctant to put forward, or even admit, that such developments can be theorized, social scientists have been attempting in recent years to advance such explanations for the advent of rule of law in the West (North et al. 2009; Fukuyama 2011) or for democracy (Acemoglu and Robinson 2005). Other works have attempted to explain how control of corruption came about in modern Western countries: either due to enlightened despots who developed meritocratic recruitment and regular audits to increase state capacity-as for instance in Denmark (Mungiu-Pippidi 2015a, ch. 3) - or through a far longer path of intra-elite competition and growth of a mass of critical citizens in democracies like the United States (Wallis 2006). The reproduction of such historical mechanisms in contemporary settings cannot be taken for granted, however. Present-day societies enjoy better education, communication and mobility, on the one hand; and, on the other, traditional ties have been weakened or have vanished (with a few exceptions in a handful of Asian traditional monarchies). The challenge these days is increasingly not how to disrupt corrupt rulers as much as how to prevent new rulers from becoming corrupt in their turn. Current corrupt democracies outnumber corrupt autocracies by two to one if we combine the World Bank's Control of Corruption with Freedom House's count of electoral democracies; although, with a couple of exceptions (like Bhutan or Singapore), the least corrupt countries in the world are the oldest democracies (Table 1.1). This simply shows that democratization, despite its current challenges, has been a tremendous success, but the reduction of patrimonialism far less so.

\section{Table 1.1 Distribution of countries across control of corruption and democracy categories}

\begin{tabular}{lcccc}
\hline 2015 & $\begin{array}{c}\text { CoC Lowest } \\
\text { Tercile }\end{array}$ & $\begin{array}{c}\text { CoC Mid } \\
\text { Tercile }\end{array}$ & $\begin{array}{c}\text { CoC Top } \\
\text { Tercile }\end{array}$ & Total \\
\hline Free & 4 & 32 & 46 & 82 \\
Partially Free & 31 & 23 & 4 & 58 \\
Not Free & 32 & 13 & 4 & 49 \\
Total & 67 & 68 & 54 & 189 \\
\hline
\end{tabular}

Notes: $\quad N$ countries $=+171$. Freedom categories as provided by Freedom House; terciles determined with CoC scores for 2015.

Sources: Freedom House's Freedom in the World and World Bank Worldwide Governance Indicators. 
The main question guiding our research is precisely what explains the transition of a society from a governance norm where public resource distribution is systematically biased in favor of the power privileged to a society where the state is largely autonomous towards private interest and the allocation of public resources is based on ethical universalism (everyone treated equally and fairly) and the pursuit of social welfare (for the benefit of the majority) and if and how such a process can be engineered. In other words, we study the few governance 'virtuous circles' which have materialized after the Second World War. The collection of process-tracing cases in this volume follows the theory of development of governance espoused in books such as Johnston's Corruption, Contention and Reform (2014) and Mungiu-Pippidi's A Quest for Good Governance (2015a). The field research was carried out over a five-year project funded by the European Union (FP7 ANTICORRP).

"Any attempt to analyse the concept of corruption must contend with the fact that in English and other languages the word corruption has a history of vastly different meanings and connotations" (Heidenheimer and Johnston 2002, p. 3) - hence the importance of clarifying what we understand by corruption and its opposite, control of corruption, in the context of this book. Simply, but hopefully clearly, the widespread definition of corruption as 'deviation' from the norm of integrity applies to the individual level, while the discussion of governance orders is at a macro level. When corruption is the norm in a society, we need to understand it as a social practice or institution, not just as a sum of individual corrupt acts. We call a country 'corrupt' when we find a governance regime where corruption is institutionalized as a rule of the game; and we call the opposite 'control of corruption' when a society reaches the capacity to constrain corrupt behavior in order to enforce the norm of individual integrity in public service and politics, to prevent state capture by particular interests and thus to promote the public interest and social welfare. Control of corruption and rule of law overlap within a complex equilibrium that includes a government subject to the law; equality of citizens before the law; respect for individual rights; equal and fair distribution of public resources; and corresponding societal norms such as respect for rules and widespread observation of the ethical universalism norm. These optimal equilibria are grounded in a social order which is based on individualism and low power distance (Eisenstadt and Roniger 1984; Hofstede 1999; Husted 1999; Mungiu-Pippidi 2015a). In contrast, institutionalized corruption is based on particularism, a feature of collectivistic and status-based societies (Mungiu-Pippidi 2015a, chs. $1-2)$. 


\subsection{WHEN IS A COUNTRY SUCCESSFUL IN CONTROLLING CORRUPTION? THE DIAGNOSIS}

To understand how a country develops control of corruption-in other words a governance context where corrupt acts are a mere individual deviation from an otherwise enshrined integrity norm - we have to understand its opposite: a governance context where corruption is the norm and a widespread social practice, so it cannot be defined as a 'deviation'. Patrimonialism, as espoused by Max Weber, is a feature of governance where the public-private border is not enforced, with the consequence of authority holders appropriating public office and its benefits for themselves and their cronies (Weber 1991, p. 298). Particularism-a concept developed by Talcott Parsons (1997, pp.80-82) on the basis of Weber and further developed by Mungiu-Pippidi (2006) — is an exchange mode of collectivistic societies, encompassing a variety of interpersonal and personal-state transaction types such as clientelism, bribery, patronage, nepotism and other favoritisms, some of which imply at an individual level some degree of patrimonialism. Particularism is defined as the deviation from the ethical universalism norm of social allocation (as defined by law, rules and the modern principles of administrative impersonality, impartiality and equality, as well as by market relations) resulting in private benefit not warranted by merit.

Particularism defines not only the relations between a government and its subjects, but also between individuals in a society, and it explains why advancement in a given society is based on merit or, on the contrary, status or particular connections with influential people. If particularistic exchanges, which are carried out on the basis of status and connections versus impersonal factors (such as merit of product, price and rules), are the dominant mode in a society, markets cannot evolve from a state of imperfect competition. Similarly, particularism of transactions between state and citizens makes democracy a mere façade, as resources are systematically spoiled by authority holders and the state never manages to become autonomous from private interest, with bureaucrats and rulers colluding in the public resources spoliation game.

The existence of particularism limits access to public resources (some applicants are favored and some are discriminated against), resulting in unfair treatment. Particularism is a broader concept than corruption as it includes both criminalized forms of corruption (favor in exchange for undue profit) and what Kaufmann and Vicente (2011) labeled 'legal corruption'. In its extreme form (most government transactions are particularistic) a state can be entirely 'captured' by private interest. The 
current scholarship and policy literature on corruption uses a variety of overlapping and differently theorized concepts that mix the social and individual level, such as state capture, grand corruption, regulatory capture, government favoritism, administrative capture and petty corruption. They all describe a specific case of particularism - for instance, in clientelism parties trade favors for votes and in petty corruption tiny bureaucrats deliver public services only incentivized by bribes; but by and large all these remain particular categories of a general situation, the distribution of public resources on the basis of favoritism. If we picture governance as the set of formal rules and informal practices determining who gets what in terms of public resources, we can then imagine a continuum of public resource allocations with full particularism at one end and full ethical universalism at the other.

The outcome of particularism - a regular pattern of preferential distribution of public goods - is called 'limited access order' by North et al. (2009), 'extractive institutions' by Acemoglu and Robinson (2012a) and 'patrimonialism' by Fukuyama (2014). But essentially all these categories overlap, and all these authors acknowledge that particularism, rather than universalism, is closer to the state of nature (or the default social organization), and that the building of the opposite (a norm based on open and equal access or public integrity) is by no means guaranteed by some evolution, and has only been reached in a few cases so far. This did not deter the promoters of UNCAC, which clearly spells out the principle of ethical universalism: to date, it has been signed by over 160 countries, which have thus pledged to implement it.

Although the literature on corruption from the nineties labeled state capture as a phenomenon related to liberalizing economies after the fall of communism (Hellman et al. 2003), state capture can be a very stable governance context that can hardly be seen as 'transitional'. Moreover, political regimes and governance orders are not tightly linked. For example, in Poland, the largest and most successful of the new European Union (EU) member states, control of corruption - as measured by the International Country Risk Guide (ICRG) since 1984 — was largely unchanged between 1989 and 1998, despite the country's dramatic improvement in political pluralism. In 1998, control of corruption actually began to decline slightly, and it remained at a lower level throughout the EU accession process and even after Poland attained membership in 2004. As governance orders reflect fundamental patterns of social organization and power distribution in a society they tend to be stable once they reach a certain equilibrium, and therefore hard to transform even by means of a political regime change (Mungiu-Pippidi 2015a).

How many exchanges are particularistic versus universalistic and 
which of the two norms is dominant in any society can be measured fairly precisely, as well as indicated by most public opinion survey respondents (Mungiu-Pippidi 2015b). A simple but effective proxy is the people's expectation, as indicated in public surveys, of the accessibility of a public resource in the absence of a personal connection or bribe. Once this is established, the nature of the particularistic exchanges - status, family ties, party ties, oligarchs, moguls or monetary advantage in the form of bribes - should be investigated next, as each society has a mix of its own. Establishing what is norm and what is exception seems an anthropological venture; but the high correlation between experts and public opinion surveys shows that awareness is generally high for everyone in corrupt countries, where journalists and ordinary people alike can fairly describe how 'it works' (Kaufmann et al. 2006).

Despite the development in recent years of fact-based measurements of particularism, grounded for instance on public procurement patterns, few states have sufficient open data to allow the use of such measures for big $n$ cross-country and cross-time comparisons. We have to resort again to aggregate perception indicators, which have been severely criticized for the lack of validity, reliability and theoretical foundation they provide (Kaufman et al. 1999; Knack 2006). To place a country on the continuum we use three indicators:

1. the Control of Corruption (CoC) indicator of the Worldwide Governance Indicators (WGI) project, an aggregate measure in existence since 1996 and including most expert scores and public opinion surveys (scores are recoded from 1 to 10 , with 10 the best performer);

2. the Corruption Risk indicator from the PRS Group's International Country Risk Guide (ICRG), an expert score (ranging from 1 to 6) in existence since the early 1980 s; and

3. indicators of particularism from country diagnoses undertaken by our group of researchers.

Using the first indicator (which basically covers all corruption ratings for all countries since 1998), we can obtain a range from closed access with particularistic exchanges at one end to open access with universalistic exchanges at the other. This shows a compact group of ten countries with the best quality of governance in the world, with another 30 or so in the upper tercile; but the majority of countries score 5 or less. Simply put, the evidence seems to indicate that the world is more particularistic than universalistic. Very few developing countries are to be found in the 


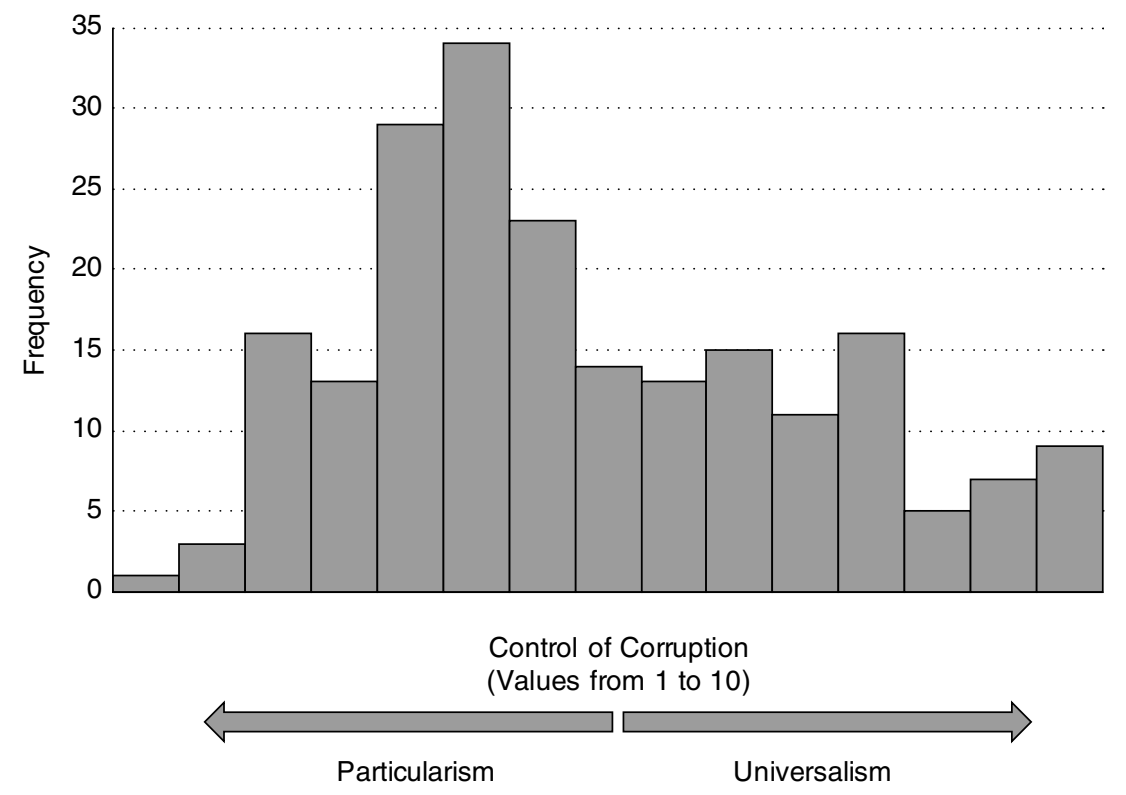

Note: WGI CoC frequency distribution, recoded 1-10 with Denmark 10. $N=209$

Figure 1.1 Distribution of countries on the particularism-ethical universalism continuum, 2015

upper tercile; and, with the exception of Japan, the 'achieving' group is composed of early European modernizers and early Anglo-Saxon colonies such as Canada, the US, New Zealand and Australia (Figure 1.1). Exceptions to the rule come only in the form of small islands or city states.

The transition away from a regime based on particularistic governance and the evolution to governance based on universalism does not come easily. Both public opinion polls and expert surveys concur in the assessment that few countries have made it, and even fewer seem to have succeeded on this path in recent times, since we have data allowing comparisons across countries and time (North et al. 2009; Mungiu-Pippidi 2015a). Furthermore, the efforts of the anti-corruption community since the birth of international promotion of good governance have yet to produce a final undisputed success case, other than what self-promoters report in general as incremental evolution (Klitgaard 2014). Many anticorruption policies and programs have been declared successful, but 
no country has yet achieved control of corruption due to international assistance and its standard prescriptions, though a few have succeeded on their own.

The definition of success also needs clarification. 'Success' can only mean a consolidated dominant norm of ethical universalism and public integrity. Exceptions, in the form of corrupt acts, will always remain; but as long as they are so numerous as to make the rule virtually indistinguishable, a country cannot be seen as an achiever. A successful transformation requires both the dominance of the norm of public integrity (the majority of acts and public officials are not corrupt) and its resilience against an eventual backslide, as happened in some Eastern European countries after EU accession. Reducing corruption to the status of exception in a sustainable way thus defines a successful evolution. Backsliding to lower quality of governance is frequently observed, since we have some indicators to trace it; but none is known from the situation when corruption has become an exception to the norm yet again (South Africa may be a strong candidate), which argues in favor of a 'tipping point' between governance orders (Wallis 1989). However, quite a few developing countries seem to be presently struggling on the borderline, where the old norm and the new norm confront one another; hence the anti-corruption headlines from such countries, where popular demand for integrity of leaders has increased substantially over the years.

The diagnosis of a governance context where particularism has become either exception or norm cannot rely only on aggregate perceptions, even if they are grounded in observations and experiences, but essentially needs fact-based indicators as well. This study surveyed six areas and observed a wealth of indicators to establish the nature of the governance order and its change across time. A summary is presented in Table 1.2, but each case study resorts also to additional indicators. The main research question guiding the choice of indicators is empirical: what are the most common practices and norms (expectation shaping behavior) in every area surveyed which encompass particularism and its outcomes for public policy? A more comprehensive discussion can be found in Mungiu-Pippidi (2015a, chs. 1-2). 


\section{Table 1.2 Diagnosis tool for assessing particularism as governance norm}

Diagnosis questions Indicators

\section{Power distribution}

- Is influence distributed unevenly, resulting in constant preferential treatment of certain groups by the state?

- Is it only one group (network/estate) which enjoys privileges?

- Is this consistent over time or does it change with elections or government succession?

- Is there one particular group that constantly loses due to power inequality?

- Does the 'loser' group have any voice?

Autonomy of the state towards private interest

- Is the state autonomous from, or captured by private interests?

- How politicized is the administration and the public sector in general?

- Is there a permanent bureaucracy which does not change with elections and how much influence does it have over policy formulation and implementation?

- Is this bureaucracy well trained and paid to fulfil its functions?

- Are policy formulation and public spending transparent, observable by and consulted with civil society and stakeholders?

\section{Public resource allocation}

- Is the main goal of the state to cater to everyone, or to special interests or groups?
- Real power held by the same individuals or networks regardless of the outcome of elections

- Persistence of widespread popular perceptions of government corruption despite changes in government

- High political migration from opposition parties to the party in government in search of political rents

- Degree of politicization (to what level personnel reshuffling occurs at government change)

- Presence of business politicians. To what extent rulers and politicians are also successful private entrepreneurs

- Share of the market for businesses with political ties

- Main fortunes related to government favoritism (public contracts, monopolies, subsidies) rather than market

- Government subnational transfers per government versus opposition areas 


\section{Table 1.2 (continued)}

Diagnosis questions Indicators

- Does the party/clan in government distribute mostly to itself (connected local governments or regions, favorite companies)?

- How much of the total spending budget are rents? Does this change from one government to the next?

\section{Public private separation}

- To what extent is the norm that a public position or advantage is passed down in a family or used for family profit?

- Is it customary that rulers/officials use public funds (or administrative resources) to cover private expenses?

- Is there any public scrutiny and disclosure of such expenses?

- Is there any moral outrage at such disclosures or is the practice accepted?

\section{Relation formal-informal institutions}

- Is the dominant norm closer to the formal or the informal institution?

- Is the formal institution subverted/ competed by the informal one?

- Is there an effort to enforce formal (legal) norms?

- How long has the gap existed between formal and informal institutions?
- Pork barrel allocations by MPs

- Size of rentier public companies

- Wages in the public sector compared to private

- Existence of companies which are successful only due to political connections manifested in preferential public contracts, concessions or subsidies

- Nepotism in the executive, legislative, judiciary

- Cases of use of administrative resources for private goals

- Offices or actual jobs in the public sector passed on by holders or managers without any real competition

- Multitude of unimplemented and unobserved rules and regulations

- Discretionary application of law, but roughly according to status

- Existence of well-known patterns of making the inefficient state sector deliver (connections, bribe to gatekeepers, brokers, etc) 
Table 1.2 (continued)

Diagnosis questions

Accountability versus culture of impunity

- Has anyone belonging to the chief status group (clan, party, or family) ever been deposed from an official position or sentenced by a court?

- Are reports of wrongdoing by such people ever followed up with public investigations?

- Do people as a rule officially complain of unfair treatment from authorities?

- Are there any whistleblowers?

- Do regular reports on government activity exist at end year/mandate, including information on objectives which were not reached and measures taken to rectify them?
Indicators

- Widespread perception in surveys that politicians are above the law, perception of political parties as top 'status groups' and political affiliation as indispensable for economic success

- Open and outrageous displays of unjustifiable wealth by public officials

- Cases of notorious rule or law breaking by status holders (not only corruption, but, for instance, traffic accidents) not followed, as a rule by prosecution of every kind

\subsection{HOW MANY SUCCESSFUL TRANSITIONS IN CONTEMPORARY TIMES? TRENDS AND CASE SELECTION}

Although we do not have systematic comparative assessments of corruption to go further back than the 1980s, there are enough historical indicators of when countries have reached certain governance benchmarks. A wider historical compass would thus divide the achievers of good governance into generations. The first generation, which we call 'historical achievers', is comprised of 14 countries, including atypical polities such as Andorra or Liechtenstein. This generation includes:

- the Scandinavian countries, which were created as a result of diverse secessions but which have forged their own paths to good governance, despite their common origins;

- Britain, the classic historical performer, and the United States, its most prodigious colony; 
- the Benelux countries, which have shared the same political space for many years, although modern and post-modern Belgium might have reached somewhat lesser standards of governance than the Netherlands;

- three historical German-speaking principalities (Austria, Prussia and Bavaria); and

- France and Switzerland (Mungiu-Pippidi 2015a).

Their achievement in governance has largely coincided with their modernity, leading to the belief reflected in UNCAC that the two can only go together, despite serious skepticism on this account voiced in the past (Nye 1967; Huntington 1968). This group of countries retains a considerable advance in their performance on governance, including control of corruption (Figure 1.2), government effectiveness and the rule of law.

The second generation of 'early' achievers reached modern governance between the two World Wars. These were generally new states that seceded from a first-generation achiever, mainly British Empire splinters mostly populated by European Christians (Ireland, Australia and New Zealand, whose evolutions continued after World War II) that continued to follow the tradition of British legal institutions, mixed with their own democratic developments. In some cases, like Ireland, the further independence was from this origin, the more control of corruption declined, according to recent accounts (Byrne 2012). Also included in this group is Iceland, a splinter of Denmark.

Finally, contemporary 'achievers' came close to the good governance benchmark after the Second World War, starting with two countries which evolved as Western protectorates following military occupation: Japan and West Germany, both on preexisting roots. More recent achievers included a new round of former British colonies, in particular Caribbean islands, a handful of Mediterranean and Eastern European countries, plus some continental exceptions. This suggests that, historically, only a few countries achieved the benchmark of 'control of corruption' independently. There appear to be only a few streams and a few exceptions from broader continental contexts. And since the World Bank began monitoring the WGI in 1996, it seems that very few countries have managed to evolve in controlling corruption, despite the development of an international legal anti-corruption framework and increased awareness of the systematic nature of corruption as a result of efforts by non-governmental organizations (NGOs) such as Transparency International. CoC, due to its aggregate nature, is not very sensitive to change; but we do find changes on the lower part of the scale. It is just transformation from the middle to the top tercile where we see insufficient change, despite a good number of 


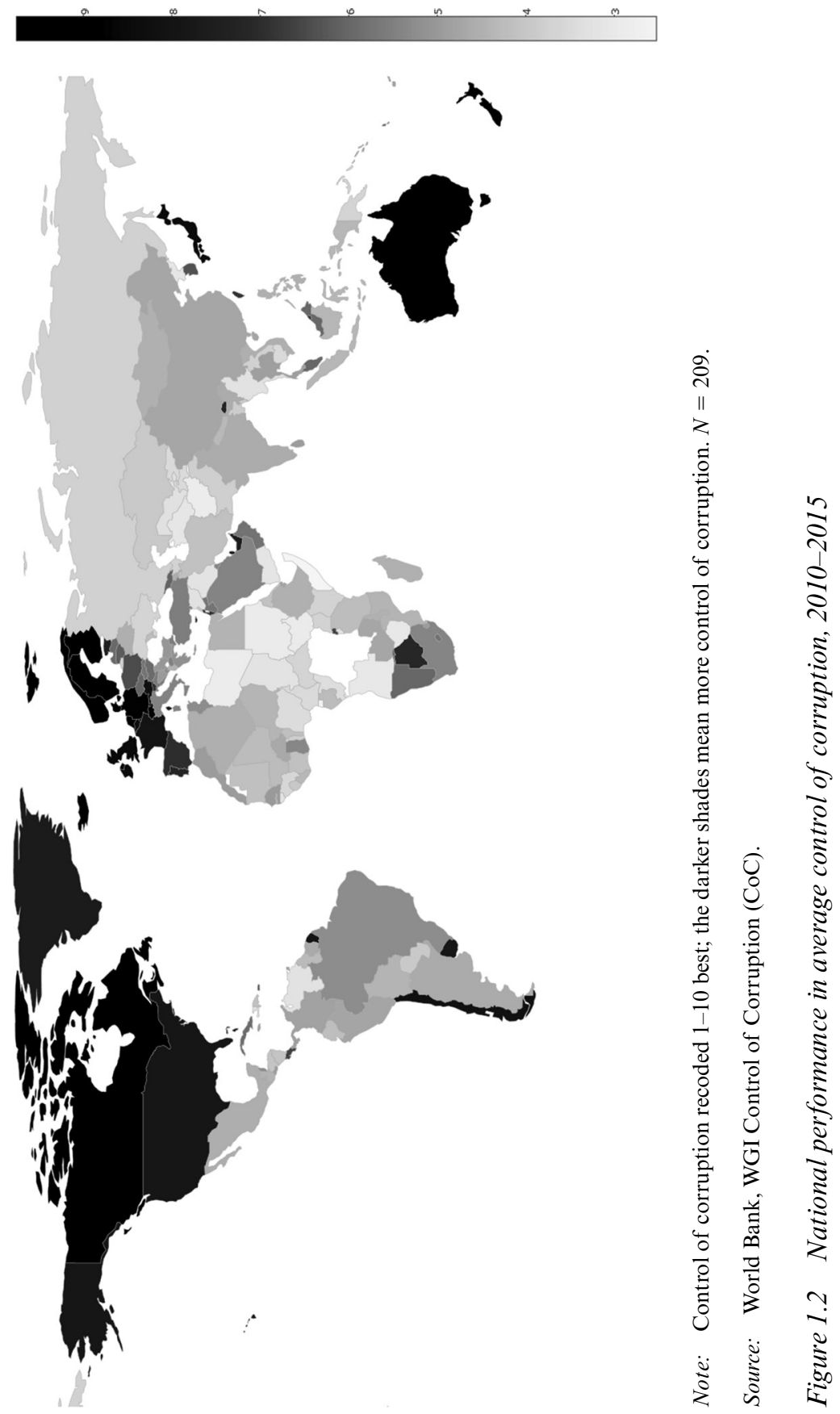




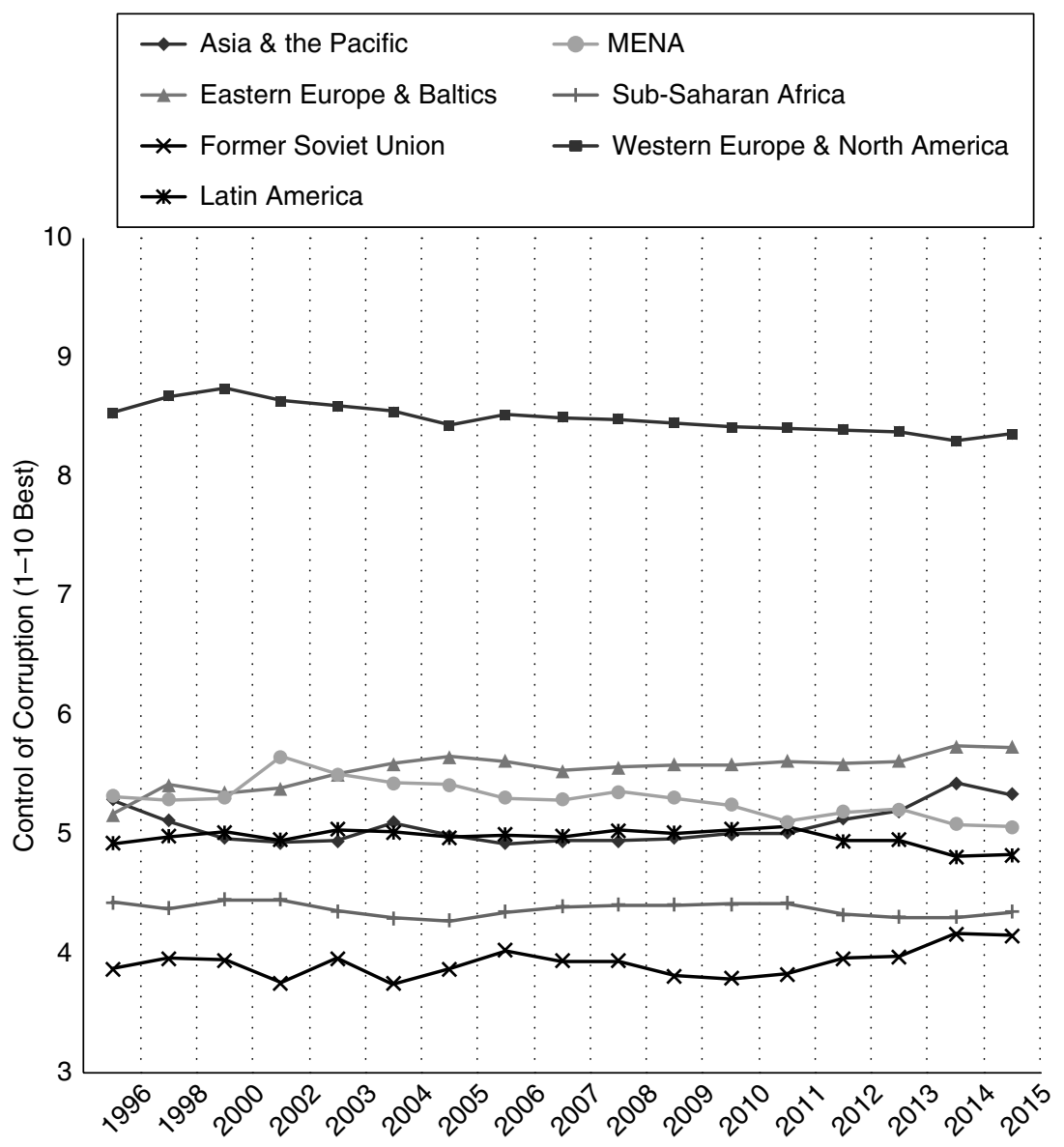

Note: The sample of countries for 1996 includes 190 countries, whereas the sample for 2015 includes 209 countries.

Source: WGI CoC (1996-2015), recoded 1-10 best.

Figure 1.3 Evolution of WGI Control of Corruption average by region, 1996-2015

countries being clustered on the borderline (Figure 1.3). But very few have made it to the group of top performers so far. Some of the countries that had evolved within the previous decades have in fact regressed since global anti-corruption efforts from around 2000.

We can therefore make two observations with high certainty. The first is that few successful transitions exist, and that they tend to unfold 
over greater intervals of time than just 15 years. The second is that little positive change has occurred in general for the past 20 years for which we have some measurements (and not many more for the past 30, as ICRG's measure lags even more than $\mathrm{CoC}$ ). According to the WGI $\mathrm{CoC}$ indicator, there has been little statistically significant change in this period, and Eastern Europe (which includes only the Baltic states from the former Soviet Union that are now EU members,) is the only region which has registered constant, albeit small, progress (see Figure 1.3). Surveys are more difficult to compare across time; but, taking into account the number of countries polled, they also fail to show significant positive evolution (Mungiu-Pippidi 2015a, ch. 1). Positive changes were experienced in two regions: post-communist Central Europe and South East Asia. The former progressed constantly, more so in the decade of the fall of the Berlin wall than afterwards; the latter first regressed after the global economic crisis, but then redressed, ending with small progress. Governance average trends across continents are matched by individual countries' trends, where also very few have made it to the threshold defined as the upper tercile or a rating of 6. With the exception of the EU, Oceania and North America, which are mostly doing well with not so much internal variation, few countries manage to escape the continental context and posit themselves as positive exceptions. These are, of course, the cases of interest.

Four criteria determine our selection of transition cases. First, a country must either rank in the upper third of all countries on the World Bank's Control of Corruption scale or be performing significantly better than other countries in its neighborhood or the expectation set by its human-development scores. This position has to be sustainable, in other words to have resisted at least one change of government. Second, no country can make the list unless it is on Freedom House's roster of 'electoral democracies' - autocracies cannot reasonably fulfill the ethical

Table 1.3 Significant change in control of corruption, 2000-2015

\begin{tabular}{lcccc}
\hline $2000-2015$ & Free & Partially Free & Not Free & Total \\
\hline Progressed & 12 & 7 & 3 & $\mathbf{2 2}$ \\
Regressed & 11 & 7 & 7 & $\mathbf{2 5}$ \\
Total & $\mathbf{2 3}$ & $\mathbf{1 4}$ & $\mathbf{1 0}$ & $\mathbf{4 7}$ \\
\hline
\end{tabular}

Notes: $\quad N$ countries $=+171$ (1996-2015). Freedom categories as provided by Freedom House. Regression and progression determined taking into account the confidence intervals provided by the WGI.

Source: WGI CoC (1996-2015), own calculation, recoded 1-10 best. 
universalism criteria, even if they have few bribery cases, able bureaucrats and a business-friendly climate, simply because rulers who do not risk losing power enjoy de facto immunity. Third, a country must have compiled the bulk of its corruption-control achievements in the last thirty years, since our oldest corruption indicator dates from 1984. Finally, a country has to be unexceptional, in other words have a population larger than a medium-sized city and not be a small island or a fiscal paradise for other countries to find meaningful sources of inspiration in its transition. This is why we discarded all the Caribbean candidates, despite many of them progressing in charts in the last decade, as their tiny polities profited increasingly after the economic crisis from their tax haven status.

A more recent picture of change based on the CoC (15 years) returns only 12 free countries which progressed, compared to 7 partly free and 3 not free. The 12 free cases, which registered a positive evolution from Table 1.2, would have been perfect candidates for transition; however most of them did not evolve all the way up to the upper tercile (Estonia and Uruguay are the notable exceptions), so their progress does not satisfy the transition criteria (although Latvia and Croatia made great progress in charts). From the countries selected under the first criterion, actually, quite a few cases have recorded negative evolution. The economic crisis hurt some small economies, so new EU member countries like Poland, Slovenia or Cyprus regressed (the last, dramatically, with information of it being a fiscal paradise becoming quite salient). Poland, for instance, which is the largest borderline case from Eastern Europe, also has the highest proportion of non-competitive tenders in Europe (at over 40 percent), and in areas like education and research the percentage is even higher (Mungiu-Pippidi 2015a), so it cannot be seen as an accomplished transition. Romania, which has become the latest poster child due to its assertive anti-corruption agency jailing over 20 ministers, prime ministers and generals after 2011, is still on a par with the rest of the Balkans at around 5 , and its corrupt magistrates and academics have already released many imprisoned corrupt officials on pardons for their 'academic' papers written in jail (outside jail, they were never academics). This further restricts our pool of countries.

Meanwhile, some authoritarian or semi-authoritarian countries (as well as Singapore, Qatar, the United Arab Emirates or Rwanda) have risen spectacularly to the upper tercile, well above East European cases, Israel or Mediterranean Europe (with the exception of Portugal). We therefore applied our diagnosis tool (Table 1.2) to all these countries in order to check if, beyond ratings, we are really dealing with successful transitions (Table 1.4). None were confirmed.

The situation of control of corruption ( $\mathrm{CoC}$, recoded $1-10$, with 10 


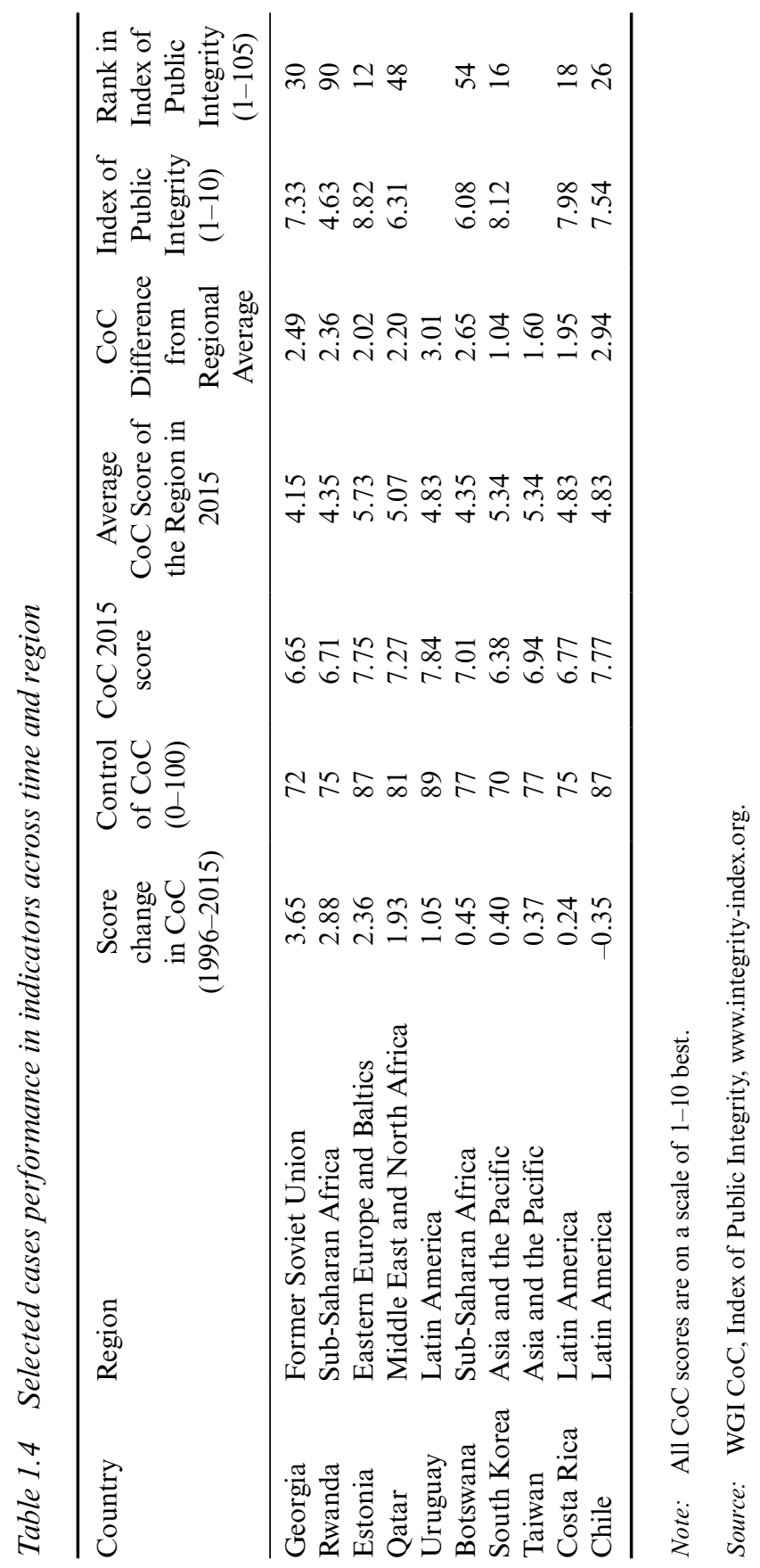


the best) by region with individual country average scores (2010-2015) can be examined in Appendix I. Botswana, Cape Verde and Rwanda top sub-Saharan Africa with best performance, with an average of 4.35 per continent and the former with scores over 7. Rwanda's evolution is the greatest over this interval, so it is worth studying to see if indeed an evolution towards ethical universalism is taking place there; its 2010-2015 average score is 6.61. For the Middle East and North Africa (MENA) the top performers are three traditional monarchies: Qatar (7.6), United Arab Emirates (7.5) and Bhutan (7.1).

Latin America has registered little recent progress (actually quite some involution), and two countries emerge as best performers, closely trailed by a third: Chile (8.1), Uruguay (7.8) and Costa Rica (6.6); but again their evolution spans more than 15 years. A wealth of Caribbean islands has recorded progress in recent years, but, due to their exceptional small size and situation as fiscal paradises (the Cayman Islands are among them), they are not included in our analysis. For Eastern Europe, Estonia (7.4) is the absolute performer, followed by Slovenia (6.9, but regressing not progressing) and Poland (6.4); however only Estonia's trend has been constantly upward. From the former Soviet Union, Georgia (6.0), has the world's largest positive trend. For Asia, Japan (8.4), an earlier achiever, remains high, with city states Singapore (9.3) and Hong Kong (8.6) the top achievers.

From more recent democracies, positive trends exist for Taiwan (6.8) catching up with older achievers who backslid, like Israel (6.9) —and South Korea (6.3), with an overall positive trend. Oceania has always done remarkably well, and Western Europe shows more involution in recent years than positive evolution: Spain (6.9), Italy (5.4), Greece (5.1), Cyprus (7.4).

By and large, excluding fiscal paradises, sparsely populated islands and city states, we are left with a list of contemporary achievers who come close to (Georgia, Costa Rica, Rwanda, Slovenia, Poland) or satisfy (Estonia, Chile, Uruguay, Botswana, Qatar, Taiwan, South Korea) our 'success' criteria. A first, mostly cross-sectional analysis of these cases exists in Mungiu-Pippidi (2015a, ch. 5). In the present volume we return with detailed country cases in order to understand what made these countries progress and to what extent this can be reproduced elsewhere. In a first stage, we identify specific progress indicators for each country in order to verify whether their advance towards ethical universalism is based on more than perception. For instance, it seems unlikely that Rwanda is indeed doing better than EU member states Romania and Bulgaria (as the WGI CoC shows) or that Qatar is better governed than half of Europe. The next chapter will discuss in some detail the discarded countries, in other words 
the achievers in the World Bank's CoC ratings that were not fully confirmed under in-depth country analysis. For the remaining cases, country experts undertook process tracing of the change process, and this is the main core of the present book.

By and large, countries could achieve control of corruption in two ways. One is surreptitious, with an incremental change of institutions until open access, free competition and meritocracy become dominant. However, they were not always (or indeed, ever) a main collective goal, but have reached accomplishment rather as a side effect or a by-product, with a gradual buildup of ethical universalism following traditional particularism (patriarchalism, as Weber called it) rather than patrimonialism. Adam Graycar's (2015) account of Australia after the Second World War suggests that major steps in control of corruption came about as a by-product. According to him, this former colony of convicts developed a high integrity (and high performance) state by addressing issues of administrative capacity rather than corruption directly. The complex of institutions built (administrative ombudsmen, for instance) were meant primarily to increase public satisfaction with service delivery-and public integrity was delivered as a side effect. This account is largely consistent with the path that Max Weber described for Germany, where particularism was gradually reduced and eliminated due to the rise of bureaucracies as tools of domination and state performance in an intra-state competition, and not due to some deliberate anti-particularism campaign.

Johann Graf Lambsdorff (2008) discussed as a theoretical possibility a similar mechanism that he called the 'invisible foot', whereby competition and other market mechanisms deliver control of corruption as an unintended consequence. The opposite way is, of course, when rule of law and control of corruption are delivered as collective goods after collective agency and investment - for instance after sustained anti-corruption campaigns. In Britain in the nineteenth century, both royal privilege and electoral corruption were curtailed after many years of such campaigns undertaken by a minority. In France, the Dreyfus affair at the turn of the twentieth century made a decisive contribution to a shift in public opinion, and also in government, with a more universalistic view of rule of law taking hold following a campaign which had lasted for nearly two decades (Mungiu-Pippidi 2015a, ch. 3). The United States also had such campaigns, particularly after dramatic increases in particularism associated with some catastrophe, such as the assassination of President Garfield in 1881 by a disappointed supporter who expected to be appointed ambassador after the victory.

The difference between these alternative paths matters both for our definition and for accounts of transitions from particularism. We define 
transition as the distance between the last moment when the rule of the game was not yet ethical universalism and the moment when ethical universalism becomes the norm. In the case of Denmark, as reported by Jensen (in Mungiu-Pippidi 2011, pp.64-70), this can be approximated as between the last moment the chiefs of staff were mostly aristocrats related to the Danish royal family and to each other (regardless of merit) and the moment aristocratic origin by itself (without merit) could no longer guarantee any such position. By 1824, very much by royal design (as wars were lost due to the incompetence of the aristocratic military class), no high public office could be occupied without a law degree from the University of Copenhagen or equivalent.

Transitions can vary in length and visibility from country to country, according to how much 'unintended consequence' versus 'agency-driven' the evolution had been. But it should always be possible to establish a moment zero and a tipping point after which the norm has shifted and people expect ethical universalism rather than particularism, so they no longer seek a connection to access a service, for instance, but just apply anonymously as any citizen. Process-tracing is carried on between these two points with the goal of producing an analytic narrative, exploring how and why the change came about. The process is undertaken with all hypotheses open and has two main advantages: it eliminates reverse causality and endogeneity problems, as it can follow the succession of events in time; and it does not seek a single variable explanation, the largest source of error in most corruption and institutional quality theory. As Talcott Parsons put it (1968, p. 229):

actions do not take place separately each with a separate, discrete end in relation to the situation, but in long complicated 'chains' ... [and] the total complex of means-end relationships is not to be thought of as similar to a large number of parallel threads, but as a complicated web (if not a tangle).

In other words, governance cannot be understood in terms of simplistic models based on one dependent variable; rather they are understood as a path model, where variables affect one another and the tangle of reciprocal influences determines a specific path by which change does or does not happen. As transitions only exist where change took place, our main strategy in this book is to study recent achievers by means of processtracing. We also explore, in limited time series, the main hypotheses across all cases; but since our time series suffer from multiple limitations - the dependent variable is an expert score (ICRG, 1984 to the present), is not a sufficiently long time series and, any complex model would have major endogeneity problems as well as missing data-we combine qualitative and quantitative methods. Other methods have been tried for related research 
questions: case studies in North et al. (2013) or paired comparisons such as North versus South Korea by Acemoglu and Robinson (2012a). We did not choose this path as comparisons would again have had to use as a dependent variable control of corruption itself, rather than change across time in control of corruption. Also, a detailed account, both quantitative and qualitative, of the former dependent variable exists in our previous work, especially Mungiu-Pippidi (2015a, chs 3-4).

\subsection{UNDERSTANDING THE EVOLUTION TO ETHICAL UNIVERSALISM: THE MODELS}

At any given moment in time, control of corruption results from the equilibrium between opportunities (or resources) for corruption and the capacity of a society to constrain its most powerful members from extracting privileged rents. This mechanism cuts across state and society and is identifiable as a specific policy context (the inner-ring factors), as illustrated in Figure 1.4, which is however the product of a specific development history (the outer ring of the circle). Factors in the outer ring are 'structural': they

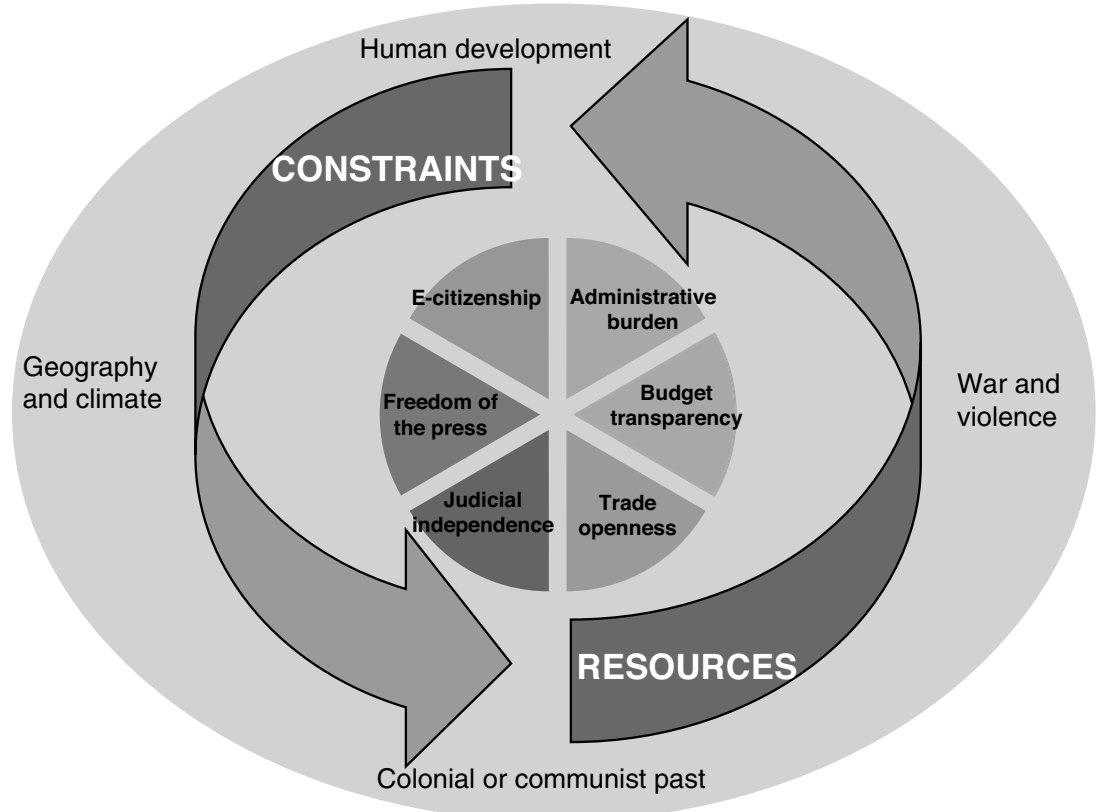

Figure 1.4 The contextual balance determining corruption control 
come from a specific geography or history and cannot be changed; they create a legacy that constrains development paths. They influence corruption indirectly, through shaping the balance between more direct factors generating opportunities for corruption (power discretion, excess regulation and bureaucracy, competition restrictions, material resources such as foreign aid, natural resources and so on) and factors creating constraints on the spoilers of public resources, such as independence of the judiciary and collective action capacity of citizens (Mungiu-Pippidi 2015a). The interaction between these factors delivers an equilibrium that can be closer to control of corruption or to actually institutionalized corruption (MungiuPippidi and Dadašov 2016).

Institutions are endogenous to contexts for the most part, which makes them hard to change. This is why we only consider from Figure 1.4 those factors from the outer ring that can change, and we discard the usually tested and significant factors such as 'former British colony' or 'island' or 'mineral resources'. We built this policy framework more recently into a new Index of Public Integrity (IPI), which measures public integrity national contexts through objective and actionable data. The time series model reported in Mungiu-Pippidi et al. (2014), Mungiu-Pippidi (2015a) and Mungiu-Pippidi and Dadašov (2016) are robust on both expert scores and survey data and have very high explanatory value (see Table 1.2). The IPI also correlates highly with fact-based indicators of corruption, such as non-competitive tenders in the European Union. Here we depart from this cross-sectional model and try to explain the evolution to the optimal equilibrium rather than its components.

In our previous work, we argued that the development of corruption control is not linear in time as political modernization increases constraints; but the growth of the state scope in modern times increases opportunities, which explains the Huntington paradox: why modernization outside Europe seems to have increased corruption instead of decreasing it (Huntington 1968; Mungiu-Pippidi 2015a, ch. 5). Furthermore, it may be precisely the failure of government rationalization (the persistence of particularism, the growth of patrimonialism) that generates what Fukuyama calls "modernization without development." As we do not agree with Fukuyama that "development is a coherent process that produces general as well as specific evolution - that is, the convergence of institutions across culturally disparate societies over time" (Fukuyama 2014, p.38; italics added) - we suggest that perhaps top-down modernization (modernization by imitation) may only increase the distance between formal and informal institutions, with negative consequences for the rule of law, state capacity and legitimacy. Huntington, in Political Order in Changing Societies, had already intimated that this was a possible development. The existence and 
persistence of a large informal economy, a companion of corrupt societies, may be the best proxy for the incapacity of some societies to avoid a suboptimal equilibrium of high opportunities for corruption and low constraints (Mungiu-Pippidi 2015a, ch. 4). With low constraints and high resources offered by mineral resources or external aid, governments never arrive at social welfare as their main goal (and development as its byproduct), but remain focused on extraction of rents (with underdevelopment as a negative externality).

What then is the solution for change from this rationalization trap? In a very synthetic way we summarize the grand alternatives.

Path 1 consists in modernization of the state. It means making changes directly to the failed organism, which is the non-rational state that has not evolved to autonomy towards private interest, public-private separation and so on. In this narrative, the solution to the failure to create a substantive rather than just nominal modern government (by not managing to create, for instance, an autonomous bureaucracy and independent judiciary) is just more top-down modernization. By and large, this path means addressing the outcome, the state as an extractive machine, rather than the causes that made it so in the first place (for instance, the large profit that rulers derive from the status quo), and building capacity of administration and judiciary as well as some transparency. This has been the path pursued most often by the anti-corruption community, leading to an explosion of integrity legislation and para-legislation and much stress on anti-corruption agencies and actions against corrupt acts after they had already occurred. In some ways, this is what the king of Denmark did in the nineteenth century, and we know that with a strong enlightened principal, in the presence of traditional authority and without a contested supreme office, this path worked.

What we lack so far are democracies to have evolved on this path in recent times, and this is what we check in our process-tracing. After all, Pritchett and Woolcock (2004) have described an intellectual fallacy of development called "when the solution is the problem," which comes dangerously close to this mechanism. Furthermore, successful anti-corruption should not take for granted that a plausible principal who is committed to advancing reform either exists or is the head of the government or institution that needs to reform. Enlightened despots are rare, and cannot be engineered. In their absence, Susan Rose-Ackerman (1997) insightfully noted that while the World Bank is concerned that its projects are not sufficiently 'owned' by borrowing countries, ownership at the top is not desirable if patronage and corruption are rife or if projects help keep corrupt regimes in power.

Path 2 can be called modernization of society. As Frank Fukuyama 
remarked (2014, pp. 184-6), the attempts to replicate the Western modern state around the world were seldom grounded in a society similar to, for instance, the British one of the nineteenth century. It is to be expected that the more similar a society grows to Western Europe at the advent of its modernization - more educated, urban, secular, gender equal, achievement oriented rather than consumption oriented - the better control of corruption it would develop. After all, the colonies that succeeded (Oceania or Canada) had the most similar societies to their European metropolis. The tipping point is then a convergence point, where social structures, economic institutions and culture align sufficiently to the Western modernization template. Historically, Peter the Great and Alexander II in Russia (Mosse 1992; Cracraft 2009) and the Meiji Restoration (1868-1912) in Japan (Beasley 2000) tried to engineer such processes of creating a modernized nation, with uneven results. Surveys of modernization as a consequence of transfer and imitation exist, allowing assessment of how national goals were set and how deep the Western imitation ran (Nettl and Robertson 1968).

The mechanism by which a society modernizes successfully enough to also experience a transition to ethical universalism is not clear. In one variant, Glaeser et al. (2004), for instance, argue that accumulation of human capital causes both economic development and superior political institutions. On the particular case of corruption, Uslaner and Rothstein (2016) argue in a similar vein that education, and especially its universalization, may play a decisive role in building control of corruption, although the statistical evidence is ambiguous, with only education in the 1900s playing a strong role.

In the framework of the same paradigm, political modernization is a rather distinct hypothesis. The proponents of this view follow Seymour Martin Lipset (1960) in believing that the increase in individual autonomy and its spread to larger groups in society (due to education, industrialization, urbanization or land reform) leads to an increased demand for inclusive institutions, and implicitly greater pressure on rulers to reduce rents. The advent of 'enlightened citizens', as Robert Dahl (1973) used to call them - as shown for instance in the newspaper readers at the turn of the twentieth century or the Internet users of the twenty-first century, additionally armed with social media as enhanced tools of association and coordination - leads to better control of corruption by pressing governments into necessary reforms through collective action.

Clearly, at least education is necessary to bring this development about, but education is not sufficient; neither are any of the modernization components unless a critical mass exists which is made up of active participating citizens and not, for instance, of consumers (Przeworski and Limongi 
1997). This is the problem of how to achieve 'strong and sustained citizen involvement', in other words how to solve the collective action problem inherent to corrupt societies where incentives are for free-riding and collusion, so the public good of integrity cannot be created (Johnston 2014, ch. 8) In our earlier work this hypothesis was treated in full as part of a "Tocquevillian" paradigm to explain deep democratization by the collective action capacity of a society (Mungiu-Pippidi 2015a, ch. 6), but lack of historical comparative data on the middle class and associations are major impediments for a full statistical test. A good account of what might be seen as a paradigmatic case is offered by Jeremy Boissevain (1977) on Malta, when he narrates how the decline of traditional associations based on patronage (around the parish church or landlords, for instance) and the increase in membership of trade unions and other secular associations led to a reduction in the vulnerability of individuals and a rise in their personal autonomy.

But whether economic development or political reform is at the start of the virtuous circle of full modernization, governance included, is a hotly debated topic. Control of corruption is seen as an unrealistic goal before a certain income threshold is reached-some researchers place it at 1800 USD/capita; but seeing the recent evolution of some sub-Saharan African cases, this may be insufficient. Only after sufficient income exists and reasonable salaries can be paid to the police, judges and civil servants, and when life expectancy is raised and enough people are educated can massive corruption be addressed, as until then bribes and connections are needed to make the state function, even if suboptimally. This was the classic approach of Samuel Huntington, who presumed that economic development could and did take place irrespective of the quality of governance. This approach is less popular today, when a significant number of economists argue that economic development cannot take place precisely due to poor institutional quality (Rodrik et al. 2004) and the intrinsic opposition of rent-seeking to free and fair competition (Mauro 1995; Ades and Di Tella 1999); but this approach is still strong, as can be seen for instance in Fukuyama's criticism (2012) of Acemoglu and Robinson.

The argument on the primacy of politics is itself not unitary, coming in various forms. The most popular in the literature concerns the decision of elites to increase political and economic rights due to the lack of sustainability of old privileges (Acemoglu and Robinson 2005), although their particular example can be further explained by a rise in demand from the masses, making it closer to the political modernization hypothesis (Mungiu-Pippidi 2015a). There is a long-running debate on the relation between democracy and corruption; but evidence points to the fact that, while autocracy is clearly less conducive to good quality of governance, 
the role of democracy is more paradoxical and complex than meets the eye, and what seems to deliver is participation of enlightened citizens over many decades - obviously in democratic settings, because otherwise such participation would not be possible at all (see Treisman 2007; MungiuPippidi 2015a, ch. 6). Table 1.1 shows that the countries with the best control of corruption are mostly free countries, but the situation is far more balanced in the other groups.

Finally, can we identify a path where control of corruption has ever resulted as an unintended consequence, even in the presence of unfinished modernization (and, with the restrictions of our case selection, in the absence of top-down enlightened human action, as in Bhutan)? Human development predicts only about half of the countries in the world: outliers are strong over-performers (New Zealand, Chile, Botswana), as well as dramatic under-performers (Argentina, Italy, Greece). The modernization model that presumes that human development should result in a certain quality of governance seems therefore to leave considerable room for exogenous factors (Appendix II shows the estimates of corruption by human development and the negative and positive outliers). They can be policies meant for other targets with unintended positive consequences for corruption, massive cultural or institutional transfers across borders (due, for instance, to military occupation) or other agency-type factors. In the absence of the right context, would such changes (even if once induced) be sustainable? All our selected 'transitions' are actually doing better than they should, considering their human development.

What does the evidence tell us of the paths to good governance? The final chapter of this book will compare the results of process-tracing with the limited but more representative evidence that statistical trend analysis can bring.

\section{REFERENCES}

Acemoglu, D., and Robinson, J. (2005). Economic Origins of Dictatorship and Democracy. Cambridge: Cambridge University Press.

Acemoglu, D., and Robinson, J. (2012a). Why Nations Fail: The Origins of Power, Prosperity and Poverty. New York: Crown Business.

Acemoglu, D., and Robinson, J. (2012b). "Response to Fukuyama's review" [blog]. Available at: http://whynationsfail.com/blog/2012/4/30/response-to-fukuyamasreview.html [accessed December 12, 2016].

Ades, A., and Di Tella, R. (1999). "Rents, competition, and corruption." American Economic Review, 89(4), pp.982-93.

Beasley, W. (2000). The Rise of Modern Japan: Political, Economic, and Social Change since 1850. London: Macmillan. 
Boissevain, J. (1977). "When the saints go marching out: Reflections on the decline of patronage in Malta." In Gellner, E. and Waterbury, J. (eds). Patrons and Clients in Mediterranean Societies. London: Duckworth.

Byrne, E. A. (2012). Political Corruption in Ireland 1922-2010: A Crooked Harp. Manchester: Manchester University Press, pp. 145-59.

Cracraft, J. (2009). The Revolution of Peter the Great. Cambridge, MA: Harvard University Press.

Dahl, R. A. (1973). Polyarchy: Participation and Opposition. New Haven, CT: Yale University Press.

Eisenstadt, S. N., and Roniger, L. (1984). Patrons, Clients and Friends: Interpersonal Relations and the Structure of Trust in Society. Cambridge: Cambridge University Press.

Fukuyama, F. (2011). The Origins of Political Order: Vol. 1. New York: Farrar, Straus and Giroux.

Fukuyama, F. (2012). "Acemoglu and Robinson on why nations fail." American Interest [online]. Available at: www.the-american-interest.com/2012/03/26/acemoglu-and-robinson-on-why-nations-fail/ [accessed December 15, 2016].

Fukuyama, F. (2014). Political Order and Political Decay. New York: Farrar, Straus and Giroux.

Glaeser, E., La Porta, R., Lopez-de-Silanes, F., and Shleifer, A. (2004). "Do institutions cause growth?" Journal of Economic Growth, 9(3), pp. 271-303.

Graycar, A. (2015). "Corruption in Australia: Making it less acceptable." Paper prepared for ANTICORRP project. Available at: www.againstcorruption.eu/ wp-content/uploads/2015/05/Graycar-Virtuous-circles-Berlin-July-2015.pptx [accessed December 9, 2016].

Heidenheimer, A., and Johnston, M. (2002). Political Corruption (3rd ed.). London: Transaction.

Hellman, J., Jones, G., and Kaufmann, D. (2003). "Seize the state, seize the day: State capture and influence in transition economies." Journal of Comparative Economics, 31(4), pp. 751-73.

Hofstede, G. (1999). "Problems remain, but theories will change: The universal and the specific in 21st-century global management." Organizational Dynamics, 28(1), pp. $34-44$.

Huntington, S. P. (1968). Political Order in Changing Societies. New Haven, CT: Yale University Press.

Husted, B. W. (1999). "Wealth, culture, and corruption." Journal of International Business Studies, 3(2), pp. 339-59.

Jensen, Mette Frisk (2011). "The traditional monarchy path to good governance." In Mungiu-Pippidi, A. (ed.). Contextual Choices in Fighting Corruption: Lessons Learned. Oslo: Norwegian Agency for Development and Cooperation.

Johnston, M. (2005). Syndromes of Corruption: Wealth, Power, and Democracy. Cambridge: Cambridge University Press.

Johnston, M. (2014). Corruption, Contention and Reform: The Power of Deep Democratization. Cambridge: Cambridge University Press.

Kaufmann, D., and Vicente, P.C. (2011). "Legal corruption." Economics and Politics, 23(2), pp. 195-219.

Kaufmann, D., Kraay, A., and Mastruzzi, M. (2006). "Measuring corruption: Myths and realities." Development Outreach, 8(2), pp. 124-37.

Kaufman, D., Kraay, A. and Zoido-Lobatón, P. (1999). "Aggregating governance indicators." World Bank Policy Research Working Paper No. 2195. 
Klitgaard, R. (2014). Addressing Corruption Together [online]. Paris: Organisation for Economic Co-operation and Development (OECD). Available at: www. oecd.org/dac/governance-peace/publications/FINAL $\% 20$ Addressing $\% 20$ corrup tion\%20together.pdf [accessed December 22, 2016].

Knack, S. (2006). "Measuring corruption in Eastern Europe and Central Asia: A critique of the cross-country indicators." World Bank Policy Research Working Paper No. 3968.

Lambsdorff, J. Graf (2008). "Good governance and the invisible foot." In Kötschau, K. and Marauhn, T. (eds). Good Governance and Developing Countries: Interdisciplinary Perspectives. Bern: Peter Lang.

Lipset, S. (1960). Political Man: The Social Bases of Politics. Garden City, NY: Doubleday.

Mauro, P. (1995). "Corruption and growth." Quarterly Journal of Economics, 110(3), pp. 681-712.

Mosse, W. E. (1992). Alexander II and the Modernization of Russia. London: Tauris.

Mungiu-Pippidi, A. (2006). "Corruption: Diagnosis and treatment." Journal of Democracy, 17(3), pp. 86-99.

Mungiu-Pippidi, A. (ed.) (2011). Contextual Choices in Fighting Corruption: Lessons Learned. Oslo: Norwegian Agency for Development Cooperation.

Mungiu-Pippidi, A. et al. (2014). "Quantitative report on causes of performance and stagnation in the global fight against corruption" [online]. Berlin: ANTICORRP. Available at: http://anticorrp.eu/publications/quantitativereport-on-causes/ [accessed October 10, 2016].

Mungiu-Pippidi, A. (2015a). The Quest for Good Governance: How Societies Develop Control of Corruption. Cambridge: Cambridge University Press.

Mungiu-Pippidi, A. (2015b). Government Favouritism in Europe: The ANTICORRP Project: Anticorruption Report. Opladen: Budrich.

Mungiu-Pippidi, A., and Dadašov, R. (2016). "Measuring control of corruption by a new index of public integrity." European Journal on Criminal Policy and Research, 22(3), pp.415-38.

Nettl, J. P., and Robertson, R. (1968). International Systems and the Modernization of Societies: The Formation of National Goals and Attitudes. London: Faber.

North, D. C., Wallis, J., and Weingast, B. (2009). Violence and Social Orders: A Conceptual Framework for Interpreting Recorded Human History. Cambridge: Cambridge University Press.

North, D. C., Wallis, J. J., Webb, S. B., and Weingast, B. R. (eds). (2013). In the Shadow of Violence: Politics, Economics, and the Problems of Development. Cambridge: Cambridge University Press.

Nye, J. S. (1967). "Corruption and political development: A cost-benefit analysis." American Political Science Review, 61(2), pp.417-27.

Offe, C. (2004). "Political corruption: Conceptual and practical issues." In RoseAckerman, S. and Kornai, J. (eds). Building a Trustworthy State in Post-Socialist Transition. New York: Palgrave Macmillan, pp. 77-99.

Parsons, T. (1968). The Structure of Social Action. New York: Free Press.

Parsons, T. (1997). Introduction to Max Weber: The Theory of Social and Economic Organization. New York: Free Press.

Pritchett, L., and Woolcock, M. (2004). "Solutions when the solution is the problem: Arraying the disarray in development." World Development, 32(2), pp. 191-212. 
Przeworski, A., and Limongi, F. (1997). "Modernization: Theories and facts." World Politics, 49(2), pp. 155-83.

Rodrik, D., Subramanian, A., and Trebbi, F. (2004). "Institutions rule: The primacy of institutions over geography and integration in economic development." Journal of Economic Growth, 9(2), pp. 131-65.

Rose-Ackerman, S. (1997). "The role of the World Bank in controlling corruption." Law and Policy in International Business, 29(1), pp. 93-114.

Treisman, D. (2007). "What have we learned about the causes of corruption from ten years of cross-national empirical research?" Annual Review of Political Science, 10(1), pp. 211-44.

Uslaner, E. M., and Rothstein, B. (2016). "The historical roots of corruption: State building, economic inequality, and mass education." Comparative Politics, 48(2), pp. 227-48.

Wallis, J. (1989). "Towards a positive economic theory of institutional change." Journal of Institutional and Theoretical Economics (JITE)/Zeitschrift für die gesamte Staatswissenschaft, 145(1), pp. 98-112.

Wallis, J. (2006). "The concept of systematic corruption in American history." In Glaeser, E., and Goldin, C. (eds). Corruption and Reform: Lessons from America's Economic History. Chicago: University of Chicago Press, pp. 23-62.

Weber, M. (1991). From Max Weber: Essays in Sociology. London: Routledge. 